работы: Книга для учителя / Под редакцией А.Н. Ростовцева. - М: Просвещение, 1996 319 с.: ил.

2. Перышкин А.В. Физика. 7 кл.: учеб. для общеобразоват. учреждений/- 12-е изд., доработ.-М.: дрофа. 2008. -192 с.: ил. ISBN 978-5-358-04480-7

3. Рощин Г.И., Самойлов Е.А., Алексеева Н.А. и др. Детали машин и основы конструирования: учеб. для вузов/; под ред. Г.И. Рощина и Е.А. Самойлова. - М.; Дрофа, 2006. - 415, [1]с.: ил. - (Высшее образование).

4. Обработка металла в школьных мастерских: Кн. для учителя. - М.: Просвещение, 1991. - 175 с.: ил.-ISBN 5-09-002661-0.

5. Технология. 5-11 классы: Проектная деятельность учащихся/ авт.-сост. Л.Н. Морозова, Н.Г. Кравченко, О.В. Павлова. - второе издание, стереотип. - Волгоград: Учитель, 2008. -204 с.

6. Черчение. 9 кл.: Учебное пособие для общеобразовательных учреждений. М.: Дрофа. 2003.-144 с.

7. http://www.findpatent.ru/

8. http://strport.ru/

9. http://supertools.com.ua/

\title{
Влияние возникновения температурных и отраженных трещин на состояние дорожной одежды
}

Кардашевский В.Д., студент, Северо-Восточный федеральный университет, 2. Якутск

E-mail: kardashvadim@mail.ru Макаров Н.М., эксперт дорожного хозяйства 1 категории, ОКК ФКУ УПРДОР «Вилюй», 2. Якутск

Копылов В.Е., инженер, Институт проблем нефти и газа ЯНЦ СО РАН, 2. Якутск

Научный руководитель: ассистент Габымев М.В.

Одним из дефектов дорожной одежды, являются трещины, появляющиеся на поверхности дорожной одежды, наличие трещин значительно уменьшает срок службы дорожной одежды. Основными причинами разрушений покрытия в виде трещин являются: воздействие транспортных нагрузок, перепады температур от положительных к отрицательным, низкие отрицательные температуры, трещины и швы в нижележащих слоях, различие теплофизических свойств материалов слоев смежных покрытий, неравномерное уплотнение земляного полотна и слоев дорожной одежды, образование пучин, сопровождающееся возникновением сетки трещин в дорожной одежде.

В зависимости от природы трещинообразование приобретает различные формы: 
- отраженные трещины;

- температурные трещины;

- силовые трещины;

- технологические трещины;

- усталостные трещины;

\section{Температурные трещины}

Температурные трещины (рис.1) являются одним из основных дефектов асфальтобетонного покрытия в Республике Саха (Якутия) и в других холодных районах мира. Они происходят, когда в верхних слоях покрытия накапливается напряжение, которое превышает предельное сопротивление покрытия растяжению. Колебание температуры может привести к непрерывному расширению и сжатию покрытия, что в конечном итоге может способствовать накоплению напряжений и трещин в асфальте [1, стр.33].

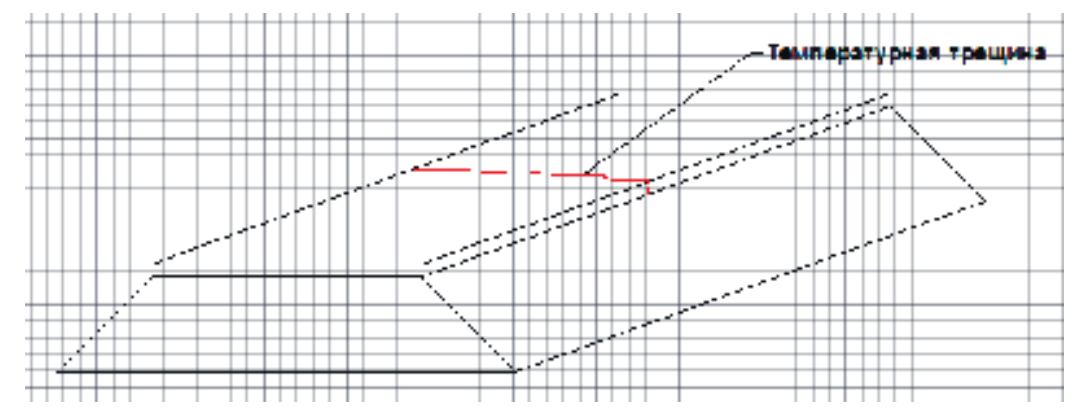

Рис. 1. Схема температурной трещины

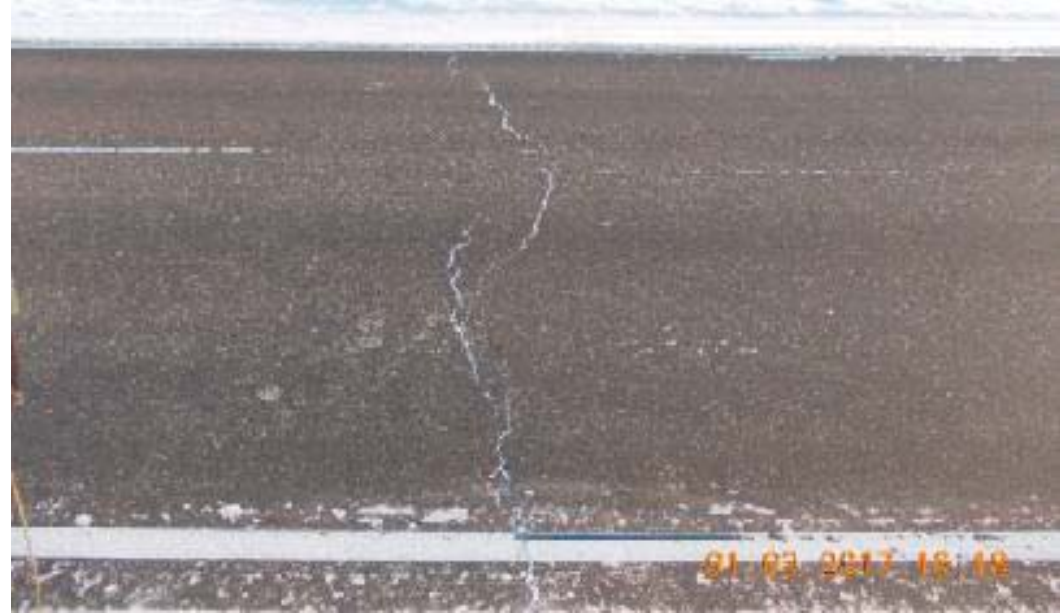

Рис. 2. Трещина на асфальтобетонном покрытии вследствие перепада температур

\section{Отраженные трещины}

Причиной образования отраженных трещин (рис.2) является наличие швов или трещин в нижележащих слоях дорожной конструкции. Отраженные трещины формируются прямо над швами или трещинами и растут постепенно снизу-вверх. Интервалы между отраженными трещинами равны интервалам между швами или трещинами в основании [1, стр.35]. 


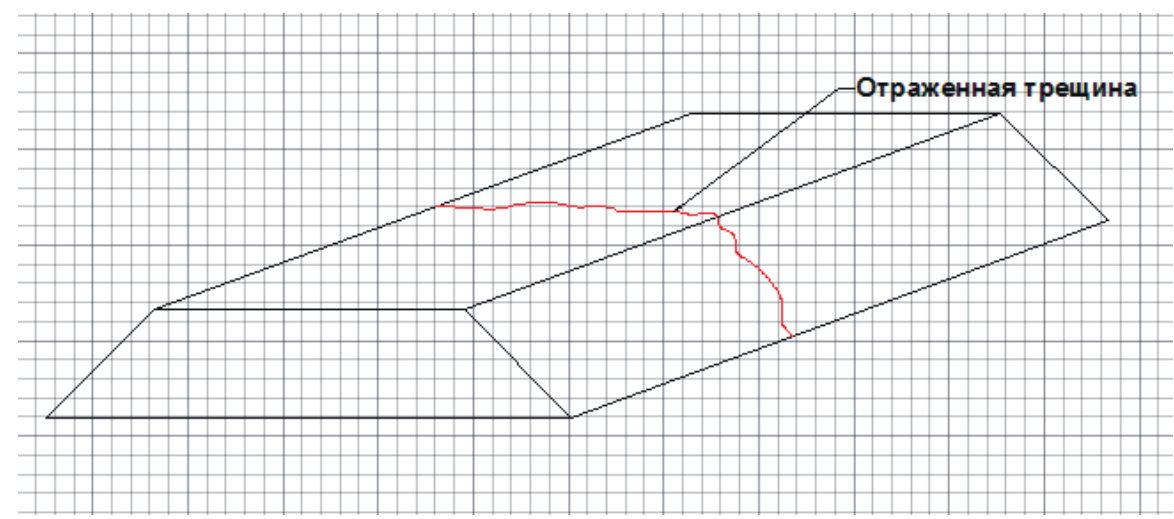

Рис. 3. Схема отраженной трещины

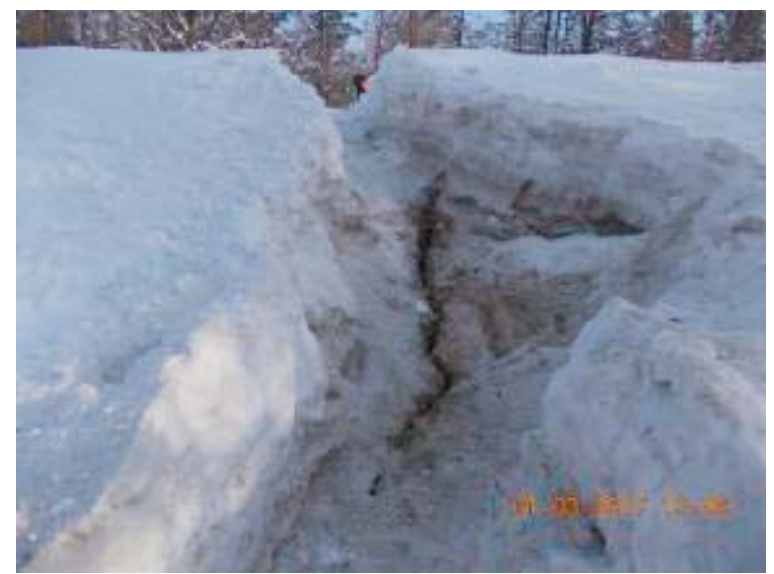

Рис. 4. Откос. Вид сбоку

Целью является определение влияния возникновения температурных и отраженных трещин на состояние дорожной одежды. Для достижения этой цели были поставлены следующие задачи:

1. Выбрать участок дороги для исследования с новой дорожной одеждой.

2. Исследовать динамику возникновения трещин.

3. Проследить за ходом развития трещин.

4. Оценить изменение состояния дорожного покрытия.

На участке капитального ремонта автомобильной дороги «Вилюй» км 150+000 км 176+000 сданном в эксплуатацию в конце 2016 года, при наступлении отрицательных температур начали образоваться трещины. Для наблюдения за развитием трещин, был выбран отрезок с км 159+000 по км 160+00 км.

Конструкция дорожной одежды рассматриваемого участка представляет собой слой основания устроенный методом стабилизации грунта, толщиной $27 \mathrm{~cm}$, щебень черный, толщиной 8cм, асфальтобетон горячий мелкозернистый марки III тип Б на БНД 90/130.

Определено количество, глубина и ширина раскрытия трещины. Использовались приборы штангенциркуль (рис.4), уровень, линейка, дорожное колесо.

По ОДН 218.0.006-2002 вычислен средневзвешенный балл $Б_{c p}$ по формуле:

$$
\mathrm{E}_{\mathrm{cp}}=\frac{\sum_{i=1}^{n} \mathrm{E}_{i} \cdot l_{i}}{\sum_{i=1}^{n} l_{i}}=0,89
$$


где $b_{i}$ и $l_{i}$ - соответствующие балл и протяженность частных микроучастков $i$ с практически одинаковым состоянием дорожной одежды в баллах; $n$ - количество частных микроучастков в составе однотипного участка [2, табл.5.16].

Всего было выявлено 87 трещин, из них температурных трещин 65 и отраженных - 22. Соотношение показано на диаграмме рисунка 5. В дальнейшем необходимо проводить мониторинги развития трещин. А также рассмотреть изменения состояния дорожного покрытия.

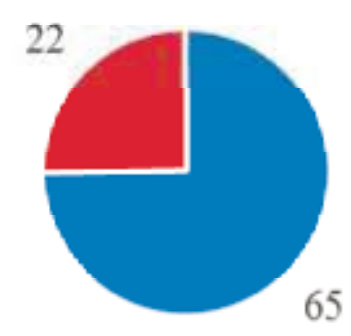

- Температурные - Морозобойные

Рис. 5. Соотношение температурных и морозобойных трещин, выявленных на участке федерального дороги «Вилюй» на км 159+00 - 160+00

Исходя из данного исследования, можно сделать следующие выводы:

1. За полгода эксплуатации состояние дорожного покрытия из нежесткой дорожной одежды на данном участке понизилось на $11 \%$.

2. Преобладают температурные трещины.

Список литературы:

1. David Sowah-Kuma. Assessment of low temperature cracking in asphalt pavement mixes and rheological performance of asphalt binders.

2. ОДН 218.0.006-2002 Правила диагностики и оценки состояния автомобильных дорог.

Повышение эффективности удаления фосфора из сточных вод на очистных сооружениях канализации г. Якутск

Константинова Т.И., стариий преподаватель, Северо-Восточный федеральный университет, г. Якутск E-mail: Tyuara_Kon@mail.ru

Очистные сооружения г. Якутска запроектированы в 1996 г. итальянской фирмой PIANIMPIANTI, при этом использована американская технология. Генеральный подрядчик проекта фирма Mabetex. Очистные сооружения включают в себя сооружения механической и биологической очистки, сооружения доочистки, обеззараживание и обработки осадка (рис. 1). 